Title of Article: Assessing the Role of Television, the Family and the School in the Development of Political Trust in Adolescence

Contributor: Sofie Marien

Journal Title: Social Science Quarterly

Volume 98 Issue 3

Copyright @ 201] by the Southwestern Social Science Association

Published by Wiley Periodicals

\title{
Assessing the Role of Television, the Family and the School in the Development of Political Trust in Adolescence
}

Democratic attitudes such as political trust are developed already early on in life (van Deth, Abendschön \& Vollmar 2011). Within the political socialization literature, the media, the family and schools are considered as critical agents within this process (Brady, Schlozman \& Verba 2015; Dewey 1926; Moeller \& de Vreese 2013). However, the nature of the influence of these agents on the development of political trust is debated. Especially, the effect of television on the development of political trust is the topic of contradicting claims in the political communication literature (Avery 2009; Curran et al. 2015; Strömbäck, Djerf-Pierre \& Shehata 2016). To date, insights from these fragmented literatures have not been integrated. It is unclear how television affects the development of political trust in adolescence and how this influence compares to other socialization agents. By drawing on both strands of literature, this study aims to gain a better understanding of the development of political trust in adolescence.

Moreover, this study also aims to contribute to the emerging field of comparative political communication. The applicability and the strength of the competing media malaise model and the media mobilization model are assumed to be influenced by the media-system (Aarts \& Semetko 2012). In this context, Aarts and Semetko $(2003,2012)$ proposed a dual effects model that predicts different effects depending on exposure to public service broadcasting or commercial channels. 
To date, the few empirical studies examining this dual effects model on political trust provide mixed results (Aarts \& Semetko 2012; Curran et al. 2015; Moy \& Pfau 2000). The bulk of these studies draws on cases in which competitive broadcasting is the norm and little attention is paid to how different media-systems shape the effects of public service broadcasting. Nevertheless, the position of public service broadcasting within the media system could influence its effects. One of the obstacles confronting comparative political communication is isolating these different types of contexts so that we can really pinpoint the influence of the media system on the attitudinal or behavioral concepts of interest. This study addresses this challenge by using a within-country comparison of the Belgian case that includes two distinct media-systems in which the importance of public service broadcasting differs strongly. This unique context allows to gain a better understanding of the role of the media in the development of political trust. In doing so, it also connects the often disparate literatures in political communication and political socialization.

A key difference between public service broadcasting stations and commercial stations relates to the key factors of the media malaise and mobilization models. Therefore, studying the influence of public service broadcasting also allows to gain more insight into the influence of television on the development of political trust more generally. Moreover, by studying different socialization agents jointly, the role of television in the development of political trust can be put in perspective. In the following sections, I briefly review the different theoretical approaches on the development of political trust building on the political communication and political socialization literature. Subsequently, the data and methods, and the results are presented, before finishing with some concluding observations on the relevance of the study of political trust among adolescents. 


\section{Television, the Family and the School as Socialization Agents}

Political trust can be considered as an important resource for any democratic political system as it determines citizens' willingness to take up their role as citizens by e.g. paying taxes or accepting political decisions (Hetherington 2005; Marien \& Hooghe 2011). Political trust can be defined as "a summary judgement that the system is responsive and will do what is right even in the absence of constant scrutiny" (Miller and Listhaug 1990, 358). Interestingly, cross-national research reveals a certain "baseline level of political trust" within a country: Some political systems are traditionally characterized by relatively high levels of political trust (e.g. in Northern Europe), while the reverse pattern can be found in other countries e.g. in Eastern Europe (Marien 2011). Trust in political authorities is rather volatile (Dabros, Parker \& Petersen 2015), but the average level of diffuse support for a political system, like citizens' trust in political institutions, is remarkably stable (Marien 2011). While this diffuse support does change over time due to for instance political scandals, political trust levels tend to return to the original level within a couple of years (Bovens \& Wille 2008). Hence, it becomes crucial to gain insight into how political trust is developed in the first place, as political trust patterns tend to be rather resistant to change once they have settled in. This study addresses this question by investigating where and how citizens learn to trust or distrust a political system.

Political socialization research reveals that adolescence is an important period in which political attitudes, such as political trust, are shaped through political socialization processes i.e. "the process, mediated through various agencies of society, by which an individual learns politically relevant attitudinal dispositions and behavior patterns" (Langton 1969, 5; Abdelzadeh, Zetterberg \& Ekman 2015; Flanagan 2013). Given adolescents' limited first-hand experience with political institutions, their knowledge is to a large extent second-hand, gathered 
by the information they receive from sources such as the media, their parents and the school (Abdelzadeh, Zetterberg \& Ekman 2015). Throughout the life cycle political trust tends to be rather resistant to long-lasting changes, causing several authors to look at intergenerational change as the driver of social change rather than individual change (Inglehart 2008; Putnam 2000). In this context, Ingehart (2008) speaks of citizens' 'formative years'. In this article the role of different socialization agents in the development of political trust in adolescence will be studied in depth, with particular attention to the role of the media.

The older political socialization literature largely neglected the media and focused primarily on the family and schools. Later on, however, television was identified as the key source of declining democratic attitudes and behavior among adolescents in Western societies (Putnam 2000). The effect of television exposure on political trust has been described by terms such as 'media malaise', ‘video malaise' or a ‘spiral of cynicism' (Cappella \& Jamieson 1996; Robinson 1976; Avery 2009). The argument goes that the 'media logic' in which the media operate leads to a focus on negative news and controversial one-liners. Politics is frequently framed in terms of a game or a competition (Cappella \& Jamieson 1996; Patterson 2015). As a result, adolescents that watch a lot of television are expected to become distrustful of the political system (Robinson 1976; Avery 2009).

This media malaise model has been challenged by scholars who emphasize the information function of television which facilitates citizen's access to political information. By watching the news and current affairs programs adolescents will become more informed, knowledgeable and enhance their understanding of public affairs and decision-making, which can in turn lead to a 'virtuous cycle' and higher levels of political trust (Norris 2000; Curran et al. 2015). Scholars have argued that the applicability and strength of the media malaise model or the media mobilization 
model depends on the media-system (Aarts \& Semetko 2012). This guides empirical research in a novel direction, more specifically as Newton $(1999,599)$ states: "into uncharted comparative waters, which will probably have to be thoroughly explored before much more headway can be made on the issue of mass media effects".

In the past decade, several scholars have taken up this challenge, though empirical studies still predominantly focus on countries in which competitive broadcasting is the norm (Aarts \& Semetko 2012). Nevertheless, especially with regard to the development of political trust, there are strong reasons to expect dual effects of public service broadcasting and commercial broadcasting. The differences in how stories are constructed and presented by public and commercial channels are exactly the key ingredients of the malaise and mobilization models (Beyer \& Matthes 2015; Jacobs, Meeusen, d'Haenens 2016). Therefore, one of the key aims of this study is to gain insight into how channel preferences affect the development of political trust in adolescence.

In effect, public service broadcast stations devote more airtime to, and deliver higher quality, information programs than commercial broadcast stations (Aarts \& Semetko 2003; Curran et al. 2012; Holtz-Bacha \& Norris 2001). Advertising dependency increases the use of sensation in topics and storytelling (Arbaoui, de Swert \& van der Brug in press). Content analyses showed public channels to be more fact-oriented, offer more hard news and attention to foreign affairs, and provide less negative and sensational news coverage (Aalberg et al. 2013; Arbaoui, de Swert \& van der Brug in press; Curran et al. 2012). These differences can be expected to result in dual effects on political trust. Due to trends of commercialization and audience fragmentation, there is the expectation of homogenization between channels. However, the current empirical evidence reveals profound differences in commercial and public channels over time, rather than a 
converging trend. Against commonly held expectations, the difference in sensationalism between commercial and public service broadcasting even increased as television systems became more fragmented (Arbaoui, de Swert \& van der Brug in press).

To date, knowledge on the influence of public service broadcasting on political trust, and on its socialization function in particular is scarce. An emerging strand of literature recently started to look into the effect of public service broadcasting on political trust (Aarts \& Semetko 2012; Curran et al. 2015; Moy \& Pfau 2000; Strömbäck, Djerf-Pierre \& Shehata 2016). Yet this political communication literature is not integrated with the political socialization literature, as a result, a comprehensive study of the effect of television on the development of political trust of adolescents is missing. In this study the influence of television exposure and content on the development of political trust during citizens' formative years is explored. Given the marked differences in the supply of information and entertainment, and in how stories are constructed and presented, I expect dual effects on the development of political trust in adolescence depending on the channels adolescents prefer. In this regard, the dual effects model of Aarts and Semetko (2003, 2012) predicts that watching commercial channels will negatively affect political attitudes and behavior, while reversed, positive, effects are expected for people that watch public channels (Aarts \& Semetko 2003; Holtz-Bacha \& Norris 2001). Studies on cases with a strong public service broadcasting tradition reveal these dual effects for political knowledge, political engagement, political efficacy and tolerance (Aarts \& Semetko 2003, Jacobs, Meeusen \& d'Haenens 2016; Holtz-Bacha \& Norris 2001; Hooghe 2002).

As different media are expected to have different effects, this study focuses on one medium, television, using a within-country comparison of the Belgian case. While other media are gaining popularity, television remains an important source of information and entertainment. Only 
a very small proportion of the Belgian population and of adolescents (approx. 3\%) do not watch any television on an average weekday (ESS round 3-6) ${ }^{\mathrm{i}}$. The overall majority of adolescents (about $78 \%$ ) and of the Belgian population (about $72 \%$ ) watches more than one hour of television on an average weekday (ESS round 3-6). Moreover, the majority of Belgian adolescents indicates that they get most information about politics and societal problems through television (BPPS 20062011, See Appendix Table A1).

Past studies predominantly focus on media-systems in which competitive broadcasting is the norm, thereby, insights into the role of television in the development of political trust in mediasystems in which public service broadcasting plays an important role, are less widespread (Aarts \& Semetko 2012). Yet it is important to extend the studied cases to gain insight into the influence of the media-system. For instance, audience fragmentation increases the difference between public and commercial channels, which is likely to increase the difference between exposure to public or commercial channels (Beyer \& Matthes 2015). The Belgian case offers a unique within-country comparative design, as the two major Belgian communities have distinct media-systems. In particular, two major media-systems exist, as media is a regional competence and the different languages in the two main communities result in two distinct public spheres. Interestingly, in the Dutch-language region the public service broadcast channels are dominant with a market share of 41.8 percent in 2012, while in the French-language region the market share of public service broadcasting is only half the size of its market share in the Dutch-language media-system (Council of Europe 2013). This offers an interesting within-country comparison that allows exploring the influence of television on the development of political trust further. By comparing both regions, the influence of public service broadcasting can be studied in different media-systems and the influence of the position of public service broadcasting within a media-system on the development 
of political trust can be explored in a unique rather controlled real-life setting. In sum, I expect that:

H1: Watching more television is related to the development of political distrust in adolescence.

H2: News consumption is related to the development of political trust in adolescence.

H3: The relation between a preference for public service broadcasting and the development of political trust in adolescence is stronger in a more fragmented mediasystem.

In addition to the media, adolescents gather political information through the family (Bandurra 1977; Gniewosz, Noack \& Buhl 2009). Within the political socialization literature, the family is argued to provide an important place for political discussion. Parents are important role models and according to social learning theory children mainly learn through observation (Bandura 1977; Brady, Schlozman \& Verba 2015). The socio-economic background of the family in which adolescents grow up is also likely to affect political trust. Parents with a higher SES have higher levels of political trust as it is easier for people with a higher socio-economic status to express trust in the social arrangements that provided them with this status (Kam \& Palmer 2008). Those who belong to the winners in society have every reason to develop a positive attitude to the system that has treated them so kindly (Newton 2007). Hence, adolescents growing up in a higher SES family are expected to have higher political trust levels.

In addition to the media and the family, political information within the schools' curriculum is likely to enhance adolescents understanding of the functioning of democracy and in 
turn their political trust. In addition to instruction about democracy, schools that function in a democratic manner can foster the development of democratic attitudes among adolescents (Dewey 1926). In particular, the concept of an 'open classroom climate' refers to classroom experiences where students are encouraged to develop and voice their opinions (Torney-Purta, Barber \& Richardson 2004). The reasoning is that experiences with a democratic functioning school lead to higher levels of trust in that specific institution, which is subsequently generalized toward the functioning of institutions in general.

While there is a general consensus that the media, the family, and the school shape adolescents' political trust, scholars have attributed different importance to them (Langton 1969; Jennings \& Niemi 1981). Few studies investigated these agents jointly and compared their effects. Moreover, given that the political communication and the political socialization literature are rarely integrated, a comprehensive study of the influence of television on the development of political trust, compared to other socialization agents, is missing. Therefore, an important aim of this study is to gain insight into the influence of television on the development of political trust, and to compare this to the influence of other socialization agents. As modern democracies are mediated democracies, especially for adolescents with even less first-hand experience with political institutions than adult citizens, I expect television to be a key socialization agent in the development of political trust.

\section{Data and method}

The influence of these socialization agents on the development of political trust is investigated using a unique high quality panel study dataset i.e. the Belgian Political Panel Study (BPPS 2006-2011, $n=3,025)$ that tracked respondents between the ages of 16 and 21. A 
representative sample of Belgian adolescents were selected through a random sample of schools that are representative of school types and location. The response rate among students was maximized by collaborating with schools which offered us one hour for students to fill in a paper and pencil questionnaire during regular class hours. A research assistant was always present to answer questions and make sure students answered the questionnaire individually. It was explicitly stated that participation was not obligatory but the students were very cooperative resulting in a very high response rate (99 percent) in the schools that agreed to participate (66 percent). Consequently, the first wave in which 6,330 sixteen-year olds participated was representative for region, school type, sex and educational track. At the age of 18 , the respondents were surveyed again at school and through regular mail at the age of 21. Respondents who had changed schools or dropped out of school received the 2008 survey by regular mail. In the second wave, 4,235 respondents (67 percent) of the first wave respondents participated. These respondents were contacted again in 2011 and 3,025 respondents or 71.4 per cent of the panel participated. Analyses on the sample show the third wave can be considered representative for the 21 years olds in Belgium (Hooghe et al. 2011).

The evolution of political trust between 2006 and 2011 is analyzed through hierarchical linear models of repeated measurements. The measures are specified as nested within individuals, which allows to investigate differences in the levels of political trust, its evolution over time as well as differences between individuals in this change over time (Maas \& Snijders 2003; Ployhart \& Vandenberg 2010). The influence of socialization agents on the level of political trust can be studied, but also whether the evolution of political trust differs for respondents with, for example, different television use. The dependent variable, political trust, was measured in exactly the same way in all waves i.e. respondents were asked to rate their level of trust in six political institutions 
on a scale from zero to ten (See Appendix - Table A2. Political institutions play an important role in shaping a democratic society, and it is assumed that trust in these institutions is strongly related to a more comprehensive evaluation of the political system. Hence, this measurement scale is widely used in political trust research (Marien 2011). The items produce an one-dimensional scale with acceptable factor loadings for the full panel and each of the three survey waves separately (See Appendix - Table A3). Therefore, a zero to ten sum-scale is used as the dependent variable, which has a mean score of 5.35 in 2006, 5.56 in 2008 and 5.16 in the 2011 wave.

The independent variables are located at different levels in the multi-level framework. At the first level, variables that change over time, measured at multiple times, are included. First, television exposure was measured by time spend before the television set on an average weekday. A modest downward trend can be observed in television exposure. To study the effect of the political information function of the media, the frequency in which adolescents followed the political news was included. This increased from approximately a fifth of the respondents following the news daily at the age of 16 to almost the majority of the respondents doing this at the age of 21. Adolescents' preference for public service broadcasting channels was included at the second, individual, level. Variables at this level are measured once and can be expected to- or are operationalized as - stable over time. While adolescents' preferences might change between 16 and 21, unfortunately, this preference was not measured in all waves. However, the findings are similar if the 2006 or 2008 measurement is included. Respondents were asked to select their preferred channels out of a list of eleven frequently watched television channels or to indicate "other" and specify which channel. They could select up to three channels. A dummy variable was created with a value of ' 1 ' indicating respondents prefer at least one public service broadcasting channel. About 4 out of 10 respondents indicated that at least one public service broadcast channel 
was among their three favorite channels.

A variable for the media-system in which respondents live is included as well as an interaction between the media-system and a preference for public service broadcasting channels to study whether the influence of public broadcasting on the development of political trust is different in different media-systems. In particular, in Belgium two major media-systems exist. While the political system and culture are kept constant, the media-system varies with the Dutchspeaking region having a dominant public service broadcast (market share around 40\%) and a less fragmented media-system and the French-speaking region having a much smaller public service broadcast (market share 20\%) and a more fragmented media-system. Hence in one political system, people are exposed to different content that varies on critical elements of the media malaise model (i.e. in the level of sensation, negative news, hard news).

To compare the influence of different socialization agents, four measures that tap into the influence of the family are included. The first variable includes adolescents' rating of how often they discuss politics with their parents, measured on a 0 (never) to 2 (frequently) scale. Second, the educational level of respondents' father is included with three categories including lower secondary at the highest, secondary at the highest and obtained higher education ${ }^{\text {ii }}$. Third, a dummy variable measuring respondents' educational goal, which has also been linked to the SES of the family, is included (1=higher education) (Kam \& Palmer 2008). Fourth, an estimate of the number of books at home is included $(0=$ less than 10 none to $4=$ more than 200$)$ as a standard additional proxy variable of the respondents' socio-economic status. As it is difficult to question adolescents directly about their parents' level of income or social class, previous research revealed the number of books at home is a good proxy for the socio-economic status of a household (Hahn 2003). These variables are measured in the first wave. Although minor shifts in these variables might occur, 
these variables and their impact on political trust is assumed to remain largely stable over the period of observation.

To study the influence of the school, a third - class - level is added to the hierarchical model. The analysis of the influence of the school on the development of political trust is limited to the Dutch-language region subsample within the BPPS 2006-11, as not all class-related variables are included in the French-language region subsample. At the third level, classroom instruction is included, measured by six questions on the discussion of certain topics in courses over the past school year such as the functioning of parliament. The items load on a single dimension and a 0 to 3 point sum-scale is constructed (Cronbach's $\alpha$ : 0.83; Eigenvalue: 3.30 ; Explained Variance: 55.05). Open classroom climate was measured through a traditional threeitem scale (Torney-Purta 2002). For instance, respondents were asked whether in their class, 'students are encouraged to make up their own minds about issues'. These items were also strongly correlated and used to construct a 0 to 3 point sum-scale (Cronbach's $\alpha$ : 0.62; Eigenvalue: 1.71; Explained Variance: 57.07). As interest in politics could bias recall experiences, these two class variables are aggregated to the classroom level and included at this level of the multi-level framework (For indicators and question wording: see Appendix).

Finally, control variables include the year of the survey i.e. dummy variables at the first level. This time variable also refers to the age of the respondents as all respondents were about the same age (i.e. 16 in 2006, 18 in 2008 and 21 in 2011). The sex of the respondent is included at the second, individual, level (Descriptives in Appendix, Table A4). While some of these independent variables are correlated with each other, the correlations are modest and do not affect the results of the regression analyses. 


\section{Empirical findings}

A first "unconditional means model" allowed to estimate the amount of variance at the different levels of the hierarchical framework. The results reveal significant differences between the political trust levels of 16 year old individuals as well as significant differences in the level of political trust over time i.e. significant variance between and within individuals. In an "unconditional growth model" the year dummies are included at the individual level and specified as random. This allows to investigate whether there are significant differences in the trajectories of political trust between individuals (Singer and Willett 2003). The level of political trust proves to be significantly higher in 2008 compared to the 2006 level, but significantly lower in 2011 .

With the current research design, it is not possible to make a distinction between an age and period effect. Yet it is likely that especially the decrease in trust between 2008 and 2011 is a period effect given that Belgium was confronted with a long political crisis during this period (Hooghe 2012). The variance component of this rate of change was not statistically significant, indicating that there are no significant differences between respondents in the trajectories of political trust from 2006 to 2011. Despite that during the period observed a lot of changes occurred in adolescents' life, these trajectories appear to be largely similar i.e. a drop between 2006 and 2008 and an increase between 2008 and 2011. It seems that differences between adolescents in political trust are already firmly in place at the age of 16 and remain stable within the following years.

In a next step, we investigate the influence of television on the development of political trust. While these media variables are modestly correlated with each other, including the three media variables in the model simultaneously or individually does not affect the key findings (Table 1). Contrary to the first hypothesis, the amount of time adolescents spent watching television is 
not related to political trust levels of adolescents (within models that only include this media variable as well as in more advanced models). Following the news and a preference for public broadcasting are both associated with higher levels of political trust in line with the second and third hypotheses. In sum, television influences the political trust levels of adolescents but not in the direction the media malaise thesis would expect. Interestingly, a public broadcasting preference has an effect on the development of political trust under control for exposure to news programs. Excluding this variable from the model leads to a stronger relation between a public broadcast preference and political trust. Hence, part of the relation between a public broadcasting preference and political trust seems to be mediated by the more extensive attention to information on public broadcasting channels. Preliminary analyses indeed revealed a public broadcasting preference is modestly related to watching more news programs $(0.116 ; \mathrm{p}<0.001)$. Yet the relation between public broadcasting and political trust is not entirely driven by the amount of news consumption. Recent research for instance revealed the public broadcasting channels in Flanders (Belgium) are provide less sensational news coverage, which might offer already one possible explanation for these dual effects (Jacobs et al. 2016). ${ }^{\text {iii }}$

In a next step, it is investigated whether these relationships are robust and not the result of spurious relationships. Adolescents growing up in a higher SES family might, for instance, be more exposed to public Preliminary analysis indeed revealed a significant correlation between a public broadcasting preference and the educational level of one's father $(0.096 ; \mathrm{p}<0.001)$. Yet even when controlling for SES of the family, public broadcasting preference remains significantly related to political trust. Studying different socialization agents jointly also allows to put the influence of television as a socialization agent into perspective. Model II shows that the influence of television remains firmly in place after including different variables that tap into the influence 
of the family. In addition to television, the family proves to be an important socialization agent. Adolescents growing up in families in which politics is discussed more often have higher political trust levels. Adolescents growing up in families with a higher socio-economic status (as operationalized by the educational level of the father) also have higher political trust levels. The number of books at home, however, does not have an additional significant impact on political trust. Finally, adolescents with the ambition of attending higher education have higher political trust levels. Already at the age of 16, there is a difference in adolescents' political trust levels depending on their academic aspirations, even before they attend higher education. This observation led scholars to question whether higher education has an effect on democratic attitudes and behaviors such as political trust or whether higher education is rather a proxy of other critical variables such as the socio-economic status of the family (Kam \& Palmer 2008).

As we could expect, preliminary analysis indicates that living in a media-system with a more dominant public broadcasting service is correlated with a stronger public broadcasting preference $(0.204 ; \mathrm{p}<0.001)$. Nevertheless, the influence of television on political trust can be observed in both media-systems. Both in the region with a large market share of public service broadcasting and the region with a smaller market share mere exposure is not related to political trust levels, while the content of exposure is. ${ }^{\text {iv }}$ Moreover, it seems that in a system in which public service broadcasting has a smaller market share, the influence of public broadcasting on political trust is larger $\left(\beta_{\text {SMALLER PUBLIC BROADCAST }}=0.71 ; \beta_{\text {LARGER PUBLIC BROADCAST }}=0.53\right.$ in Model 2 on the two subsamples). To test whether this difference is statistically significant, an interaction term between the media-system and a public broadcasting preference is included. The results in Model 3 do not show a significant difference between both media-systems. Hence, hypothesis 3 can only partially be confirmed. Adolescents' preferring public service broadcasting channels have higher 
political trust levels in both media-systems, despite the large differences in the public service broadcast's role in both regions.In a final model, the influence of the school on the development of political trust is studied (Table 1, Model 4). This analysis takes the form of a three-level hierarchical linear model for change with observations nested in individuals and individuals nested in classes on the Dutch-language region subsample (Singer \& Willett 2003). We can observe that the influence of television on political trust remains in place, even after adding these additional variables and modifying model specifications. Further, both classroom instruction about politics as well as experience with an open classroom climate are related to higher political trust levels. The influence of "experiencing democracy" is larger than instruction, which underscores the importance of active learning strategies for the development of democratic attitudes among adolescents (Kahne \& Westheimer 2006).

The results of these analyses allow to compare the different socialization agents and reveal that there is no dominant socialization agent as the range of the standardized coefficients is not very large. Television, the family, and the school all contribute to the development of political trust levels of adolescents. Given the absence of different trajectories in the development of political trust over time among adolescents, it seems that already at the age of 16 differences in political trust levels between adolescents are strongly in place and these differences persist within the following years. All three socialization agents are found to contribute to a similar extent to these differences in political trust levels. Moreover, all agents have an independent effect on the political trust levels of adolescents. Even when controlling for a variety of socialization agents, the effect of the media remains firmly in place. While the amount of television exposure does not prove to influence adolescents' political trust levels, the media content clearly does. Within both media-systems support can be found for a dual effects model in which public broadcasting is 
positively related to political trust while commercial broadcasts channels are related to political distrust. Moreover, there are indications that these dual effects are more pronounced in a media system with a stronger public service broadcast.

\section{[Table 1 about here]}

\section{Conclusion}

Within the public and scholarly debate concerns have been expressed repeatedly about the role of the media within the democratic process (Avery 2009; Cappella \& Jamieson 1996; Putnam 2000). While in the early socialization literature, the media was often not considered of much importance for the development of democratic attitudes and behavior, later on television was identified as the key source of declining democratic attitudes and behavior among adolescents in Western democracies (Putnam 2000). In this study, the role of the media, in particular television, as a socializing agent was investigated using a comparative political communication approach.

While there are clear theoretical reasons why the effect of television exposure on the development of political trust is influenced by the media-system, studies on the dual effect of public service and commercial stations on political trust are scarce. The frequency of watching television was found to be unrelated to the development of political trust in adolescence, while news consumption and a preference for public broadcasting channels was related to higher levels of political trust. Whereas a preference for public service broadcast stations is positively related to political trust, a preference for commercial channels is negatively related to political trust. This is in line with the emerging scholarship on the dual effects model on political trust (e.g. Curran et al. 2015). Interestingly, the more extensive news content offered by public service broadcasting 
channels contributes to its positive effect on political trust levels. But even after controlling for exposure to news programs, public broadcasting is related to political trust. Gaining additional insights into the causal mechanisms underlying this effect would offer an interesting avenue for future research as this study clearly provides evidence for the dual effects model.

The Belgian case further enabled a within-country comparison between two distinct mediasystems with a large dominant public broadcast in the Dutch-language region and a smaller public service broadcast in the French-language region. An in depth study of both cases revealed that a preference for public service broadcasting is positively related to political trust in both mediasystems, despite the strong differences in audience fragmentation and the strength of public service broadcasting. While the relationship seemed stronger in the more fragmented system, as the content of public broadcasting channels and commercial channels might be more distinctive in this system, a formal interaction test did not reveal significant differences between the two mediasystems.

In sum, this study offers additional insights into the influence of different socialization on the development of political trust in adolescence. Television, the family and the school shape political trust levels to a similar extent. It should be noted that while the most important socialization agents within the political socialization literature were taken into account, additional variation in political trust remains unexplained. Moreover, even with the use of a representative panel that tracked adolescents between 16 and 21, we should still be careful in drawing causal interferences. The possibility can not be excluded, for instance, that adolescents with a higher level of political trust have a preference for public service broadcasting. However, it is clear that the media malaise model does not hold among adolescents that watch public service broadcasting channels. 
The research design used in this study offers an original contribution to the emerging comparative political communication field by allowing a unique comparison between two distinct media-systems while keeping the political system constant. In addition to its comparative value, this study sheds light on the development of political trust in adolescence and the influence of a broad variety of socialization agents. Given that societal change is often the result of intergenerational change (Inglehart 2008) and political trust levels tend to be rather resistant throughout the life cycle, this study provides essential insights into the development of this important democratic resource. 


\section{References}

Aalberg, T. et al. (2013). International TV News, Foreign Affairs Interest and Public Knowledge: A Comparative Study of Foreign News Coverage and Public Opinion in 11 countries. Journalism Studies, 14(3), 387-406.

Aarts, K. \& Semetko, H. A. (2003). The Divided Electorate: Media Use and Political Involvement. Journal of Politics, 65, 759-784.

Aarts, K. \& Semetko, H.A. (2012). Changes in European Public Broadcasting: Potential Consequences for Political Knowledge, Attitudes and Behavior. In H.A. Semetko and M. Scammell (Eds.). Sage Handbook of Political Communication. London: Sage.

Abdelzadeh, A. Zetterberg, P. \& Ekman, J. (2015). Procedural fairness and political trust among young people: Evidence from a panel study on Swedish high school students. Acta Politica, $50(3), 253-278$.

Arbaoui, B., Swerts, K. \& van der Brug, W. (in press). Sensationalism in News Coverage: A Comparative Study in 14 Television Systems. Communication Research, in press. (DOI: https://doi.org/10.1177/0093650216663364).

Avery, J. M. (2009). Videomalaise or virtuous circle? The influence of the news media on political trust. International Journal of Press-Politics, 14(4), 410-33.

Bandura, A. (1977). Social Learning Theory. Englewood Cliffs: Prentice Hall.

Beyer, A. \& Matthes, J. (2015). Attitudes toward Illegal Immigration and Exposure to Public Service and Commercial Broadcasting in France, Norway, and the United States, International Journal of Communication, 9, 3264-3279. 
Bovens, M., \& Wille, A. (2008). Deciphering the Dutch drop: Ten explanations for decreasing political trust in the Netherlands. International Review of Administrative Sciences, 74, 283305.

Brady, H. Schlozman, K.L. \& Verba, S. (2015). Political Mobility and Political Reproduction from Generation to Generation. Annuals of the American Academy of Political and Social Science, 657, 149-173.

Cappella, J. N. \& Jamieson, K. H. (1996). News Frames, Political Cynicism, and Media Cynicism. Annals of the American Academy of Political and Social Science, 546, 71-84. Council of Europe (2013). Audiovisual Observatory Yearbook 2012. Strasbourg: Council of Europe.

Curran, J. et al. (2015). Reconsidering 'virtuous circle' and 'media malaise' theories of the media: An 11-nation study. Journalism, 15(7), 815-833.

Curran, J. et al. (2012). News Content, Media Use, and Current Affairs Knowledge. In: T. Aalberg \& J. Curran (Eds.). How Media Inform Democracy: A Comparative Approach. London: Routledge.

Dabros, M.S., Parker, S.L. \& Petersen, M.W. (2015). Assessing the Stability of Trust in Government Across Election Periods, Social Science Quarterly, 96(4), 996-1011.

Dewey, J. (1926). Democracy and Education. New York: MacMillan.

ESS Round 3-6 (2006-2012). European Social Survey Round 3-6 Data (2006-2012). Norway: Norwegian Centre for Research Data. Data Archive and distributor of ESS data for ESS ERIC.

Flanagan, C. A. (2013). Teenage Citizens. The Political Theories of the Young. Cambridge: University Press. 
Gniewosz, B., Noack, P., \& Buhl, M. (2009). Political Alienation in Adolescence: Associations with Parental Role Models, Parenting Styles, and Classroom Climate. International Journal of Behavioral Development, 33(4), 337-346.

Hahn, C. L. (2003). Democratic Values and Citizen Action: A View from Us Ninth Graders. International Journal of Education Research, 39(6), 633-642.

Hetherington, M. J. (2005). Why Trust Matters. Princeton: University Press.

Holtz-Bacha, C., \& Norris, P. (2001). To Entertain, Inform and Educate: Still the Role of Public Television. Political Communication, 18, 123-140.

Hooghe, M. (2012). The Political Crisis in Belgium (2007-2011): A Federal System without Federal Loyalty, Representation, 48(1), 131-138.

Hooghe, M. (2002). Watching television and civic engagement. Disentangling the effects of time, programs, and stations. Harvard International Journal of Press/Politics, 7, 84-104.

Hooghe, M. et al. (2011). Belgian Political Panel Survey (BPPS), 2006-2011. Technical Report. Leuven: University of Leuven.

Inglehart, R. (2008). Changing Values Among Western Publics from 1970 to 2006. West European Politics, 31(1-2), 130-146.

Jacobs, L., Meeusen, C. \& d'Haenens, L. (2016). News Coverage and Attitudes on Immigration: Public and Commercial Television News Compared. European Journal of Communication, $31(6), 642-660$.

Jennings, M.K. \& Niemi, R.G. (1981). Generations and Politics: a Panel Study of Young Adults and Their Parents. Princeton: University Press.

Kahne, J. \& Westheimer, J. (2006). The Limits of Efficacy: Educating Citizens for a Democratic Society. Political Science and Politics, 39, 289-296. 
Kam, C. \& Palmer, C. (2008) Reconsidering the Effects of Education on Political Participation, Journal of Politics, 70(3), 612-631.

Langton, K.P. (1969). Political Socialization. Oxford: University Press.

Maas, C. J. \& Snijders, T.A.B. (2003). The Multilevel Approach to Repeated Measures for Complete and Incomplete Data, Quality and Quantity, 37(1), 71-89.

Marien, S. (2011). Measuring Political Trust Across Time and Space. In M. Hooghe, \& S. Zmerli (Eds.), Political Trust. Why Context Matters. Colchester: ECPR Press.

Marien, S. \& Hooghe, M. (2011). Does Political Trust Matter? An Empirical Investigation into the Relation between Political Trust and Support for Law Compliance. European Journal of Political Research, 50(2), 267-291.

Miller, A. H. \& Listhaug, O. (1990). Political Parties and Confidence in Government. A Comparison of Norway, Sweden and the United States. British Journal of Political Science, 20(3), 357-386.

Moeller, J. \& de Vreese, C. (2013). The differential role of the media as an agent of political socialization in Europe, European Journal of Communication, 28(3), 309-325.

Moy, P. \& Pfau, M. (2000). With Malice Toward All? The Media and Public Confidence in Democratic Institutions. Westport: Praeger.

Newton, K. (2007). Social and Political Trust. In R. Dalton \& H.-D. Klingemann (Eds.), Oxford Handbook of Political Behaviour. Oxford: Oxford University Press.

Newton, K. (1999). Mass media effects. Mobilization or media malaise? British Journal of Political Science, 29(4), 577-99.

Norris, P. (2000). A Virtuous Circle: Political Communications in Postindustrial Societies. Cambridge: Cambridge University Press. 
Patterson, T.E. (2015). Game versus Substance in Political News. In: Kenski, K. \& Jamieson, K.H. (eds). The Oxford Handbook of Political Communication. Oxford: Oxford University Press. Published online March 2015.

Ployhart, R. E. \& Vandenberg, R.J. (2010). Longitudinal Research: The Theory, Design, and Analysis of Change, Journal of Management, 36(1), 94-120.

Putnam, R. D. (2000). Bowling Alone. The Collapse and Revival of American Community. New York: Simon and Schuster.

Robinson, M. J. (1976). Public Affairs Television and Growth of Political Malaise. Case of Selling of Pentagon. American Political Science Review, 70(2), 409-432.

Singer, J. D. \& Willett, J.B. (2003). Applied Longitudinal Data Analysis: Modeling Change and Event Occurrence. New York: Oxford University Press.

Strömbäck, J., Djerf-Pierre, M. \& Adam Shehata, A. (2016). A Question of Time? A Longitudinal Analysis of the Relationship between News Media Consumption and Political Trust. The International Journal of Press/Politics, 21(1), 88-110.

Torney-Purta, J. (2002). The School's Role in Developing Civic Engagement: A Study of Adolescents in Twenty-Eight Countries. Applied Developmental Science, 6(4), 203-212. Torney-Purta, J., Barber, C., \& Richardson, W. (2004). Trust in Government-Related Institutions and Political Engagement among Adolescents in Six Countries. Acta Politica, 39, 380-406. van Deth, J. Abendschön, S. \& Vollmar, M. (2011). Children and Politics: An Empirical Reassessment of Early Political Socialization. Political Psychology, 31(1), 147-14. 


\section{Notes}

${ }^{\mathrm{i}}$ These figures are drawn from the European Social Survey in the period of observation of this study (2006-2012).

ii The educational level of the mother was included as well but did not have an effect. To arrive at a parsimonious model this variable was not included in the final models.

iii Additional analyses reveal the same patterns with internet use. While internet is unrelated to the development of political trust, using the internet to gather news is positively related to political trust levels.

${ }^{\text {iv }}$ Within the French-speaking region, public and commercial channels from France are also watched. In the sample for instance $8 \%$ indicates that France 2 and 5\% indicates that France 3 is among one's top 3 channels. Therefore, I also tested whether taking into account preferred public channels from France affected the results. The additional analyses reveal that the results are robust. 


\section{TABLES}

Table 1. The influence of Television, the family and the School on the Development of Political Trust

\begin{tabular}{|c|c|c|c|c|c|c|c|c|c|c|}
\hline & \multicolumn{2}{|l|}{ Model I } & \multicolumn{3}{|l|}{ Model II } & \multicolumn{2}{|l|}{ Model III } & \multicolumn{3}{|l|}{ Model IV } \\
\hline & $\mathrm{b}$ & s.e. & $\mathrm{b}$ & s.e. & $\beta$ & $\mathrm{b}$ & s.e. & $\mathrm{b}$ & s.e. & $\beta$ \\
\hline \multicolumn{11}{|l|}{ Media } \\
\hline Time watching TV & -0.020 & 0.027 & 0.024 & 0.027 & 0.010 & 0.024 & 0.027 & 0.019 & 0.034 & 0.008 \\
\hline News consumption & $0.173 * * *$ & 0.020 & $0.149 * * *$ & 0.020 & 0.081 & $0.149 * * *$ & 0.020 & $0.101 * * *$ & 0.025 & 0.056 \\
\hline Public broadcast & $0.339 * * *$ & 0.058 & $0.225^{* * *}$ & 0.057 & 0.061 & $0.195 * *$ & 0.066 & $0.190 * *$ & 0.067 & 0.053 \\
\hline Media-system (1=FR) & $-0.157 * *$ & 0.059 & $-0.298 * * *$ & 0.060 & -0.079 & $-0.329 * * *$ & 0.069 & & & \\
\hline $\begin{array}{l}\text { Interaction: public * media- } \\
\text { system }\end{array}$ & & & & & & 0.118 & 0.129 & & & \\
\hline \multicolumn{11}{|l|}{ Family } \\
\hline Discuss politics with parents & & & $0.226 * * *$ & 0.045 & 0.079 & $0.227 * * *$ & 0.045 & $0.220 * * *$ & 0.057 & 0.076 \\
\hline Father higher educated & & & $0.131 * *$ & 0.038 & 0.054 & $0.130 * *$ & 0.038 & $0.142 * *$ & 0.048 & 0.058 \\
\hline Books at home & & & 0.023 & 0.021 & 0.018 & 0.022 & 0.045 & 0.019 & 0.026 & 0.015 \\
\hline Educational goal & & & $0.639 * * *$ & 0.072 & 0.139 & $0.641 * * *$ & 0.073 & $0.498 * * *$ & 0.093 & 0.114 \\
\hline \multicolumn{11}{|l|}{ School } \\
\hline Classroom instruction & & & & & & & & $0.256^{*}$ & 0.124 & 0.049 \\
\hline Classroom climate & & & & & & & & $0.466^{*}$ & 0.184 & 0.060 \\
\hline \multicolumn{11}{|l|}{ Control variables } \\
\hline \multicolumn{11}{|l|}{ Year (ref: 2006) } \\
\hline 2008 & $0.177 * * *$ & 0.037 & $0.188 * * *$ & 0.037 & 0.050 & $0.188 * * *$ & 0.037 & $0.203 * * *$ & 0.046 & \\
\hline 2011 & $-0.291 * * *$ & 0.039 & $-0.266^{* * *}$ & 0.039 & -0.071 & $-0.266^{* * *}$ & 0.037 & $-0.252 * * *$ & 0.049 & 0.054 \\
\hline Female & $0.255 * * *$ & 0.054 & $0.156^{* *}$ & 0.053 & 0.046 & $0.160 * *$ & 0.054 & 0.089 & 0.070 & 0.025 \\
\hline Intercept & $4.785 * * *$ & 0.073 & $3.918 * * *$ & 0.100 & & $3.927 * * *$ & 0.100 & $3.129 * * *$ & 0.335 & -0.067 \\
\hline Within person & 1.310 & 0.054 & 1.199 & 0.051 & & 1.199 & 0.051 & 1.049 & 0.064 & \\
\hline In initial status & 1.700 & 0.034 & 1.695 & 0.051 & & 1.695 & 0.041 & 1.674 & 0.050 & \\
\hline In rate of change & 0.000 & 0.000 & 0.000 & 0.003 & & 0.000 & 0.003 & 0.000 & 0.004 & \\
\hline Within class & & & & & & & & 0.125 & 0.044 & \\
\hline LL & -14 &, 430.234 & & & ,347.977 & & & & & 139.693 \\
\hline $\mathrm{N}_{\text {observations }}$ & & 7,651 & & & 7,651 & & & & & 4,903 \\
\hline $\mathrm{N}_{\text {individuals }}$ & & 2,641 & & & 2,641 & & & & 82 (in 20 & classes) \\
\hline
\end{tabular}

Source: BPPS 2006-11. Note: : Entries are the result of a hierarchical linear model with repeated measures nested in individuals. Model IV includes a three-level model with repeated measures nested in individuals which are nested in classes. Sig. levels: *:p $<0.05 ;{ }^{* *}: \mathrm{p}<0.01 ; * * *: \mathrm{p}<0.001$. Baseline model LL: $-14,562.649$. Within person variance: $1.387(0.056)$. Variance in initial status: $1.747(0.035)$. Variance in rate of change: $0.000(0.000)$. 


\section{Appendix}

Table A1. Source of adolescents' information of societal problems and politics

\begin{tabular}{lc}
\hline & Percentage \\
\hline Television & 51.3 \\
Family & 15.1 \\
Newspapers & 10.3 \\
Radio & 7.8 \\
Internet & 5.1 \\
School & 4.4 \\
Friends & 2.8 \\
I do not get such information & 3.3 \\
\hline
\end{tabular}

Source: BPPS (2006-2011). Note: Results to survey question 'Where do you get most information on societal problems and politics? (Answering possibilities in the table, only one option possible).

Table A2. Descriptives for Political Trust Items

\begin{tabular}{lccc}
\hline & Min-Max & Mean & Std. Dev. \\
\hline 2006 & $0-10$ & 5.681 & 2.347 \\
Police & $0-10$ & 5.951 & 2.268 \\
Courts & $0-10$ & 5.052 & 2.247 \\
Federal Parliament & $0-10$ & 5.168 & 2.190 \\
Regional Parliament & $0-10$ & 5.694 & 2.318 \\
European Parliament & $0-10$ & 4.527 & 2.238 \\
Political Parties & $0-10$ & 5.345 & 1.835 \\
Political Trust 2006 (sum-scale) & & & \\
2008 & $0-10$ & 6.025 & 2.328 \\
Police & $0-10$ & 6.357 & 2.163 \\
Courts & $0-10$ & 5.043 & 2.215 \\
Federal Parliament & $0-10$ & 5.441 & 2.158 \\
Regional Parliament & $0-10$ & 5.973 & 2.204 \\
European Parliament & $0-10$ & 4.543 & 2.128 \\
Political Parties & $0-9.667$ & 5.564 & 1.767 \\
Political Trust 2008 (sum-scale) & & & \\
2011 & $0-10$ & 5.948 & 2.196 \\
Police & $0-10$ & 5.891 & 2.095 \\
Courts & $0-10$ & 4.578 & 2.128 \\
Federal Parliament & $0-10$ & 5.115 & 2.149 \\
Regional Parliament & $0-10$ & 5.667 & 2.243 \\
European Parliament & $0-10$ & 3.785 & 2.088 \\
Political Parties & $0-9.333$ & 5.164 & 1.648 \\
Political Trust 2011 (sum-scale) & questions "can you indicate for each of the \\
\hline Source: BPPS 2006-2011. Note: results of survey & &
\end{tabular}


Table A3. Factor Analysis for Trust in Political Institutions

\begin{tabular}{|c|c|c|c|c|c|c|c|c|}
\hline & \multicolumn{2}{|c|}{ Panel } & \multicolumn{2}{|c|}{ Wave I (2006) } & \multicolumn{2}{|c|}{ Wave II (2008) } & \multicolumn{2}{|c|}{ Wave III (2011) } \\
\hline & $\begin{array}{c}\text { Factor } \\
\text { load }\end{array}$ & $\begin{array}{c}\text { Cron- } \\
\text { bach's } \alpha \\
\text { without } \\
\text { item }\end{array}$ & $\begin{array}{l}\text { Factor } \\
\text { load }\end{array}$ & $\begin{array}{l}\text { Cron- } \\
\text { bach's } \alpha \\
\text { without } \\
\text { item }\end{array}$ & $\begin{array}{l}\text { Factor } \\
\text { load }\end{array}$ & $\begin{array}{l}\text { Cron- } \\
\text { bach's } \alpha \\
\text { without } \\
\text { item }\end{array}$ & $\begin{array}{c}\text { Factor } \\
\text { load }\end{array}$ & $\begin{array}{l}\text { Cron-bach's } 0 \\
\text { without item }\end{array}$ \\
\hline Police & 0.610 & 0.882 & 0.623 & 0.895 & 0.639 & 0.888 & 0.572 & 0.858 \\
\hline Courts & 0.677 & 0.870 & 0.676 & 0.887 & 0.681 & 0.879 & 0.668 & 0.840 \\
\hline $\begin{array}{l}\text { Federal } \\
\text { parliament }\end{array}$ & 0.864 & 0.844 & 0.901 & 0.857 & 0.867 & 0.855 & 0.821 & 0.817 \\
\hline $\begin{array}{l}\text { Regional } \\
\text { parliament }\end{array}$ & 0.876 & 0.843 & 0.903 & 0.858 & 0.885 & 0.853 & 0.840 & 0.815 \\
\hline $\begin{array}{l}\text { European } \\
\text { parliament }\end{array}$ & 0.769 & 0.858 & 0.791 & 0.872 & 0.761 & 0.870 & 0.754 & 0.828 \\
\hline $\begin{array}{l}\text { Political } \\
\text { parties }\end{array}$ & 0.674 & 0.873 & 0.702 & 0.884 & 0.709 & 0.877 & 0.606 & 0.853 \\
\hline Eigen value & 3.391 & & 3.588 & & 3.488 & & 3.088 & \\
\hline $\begin{array}{l}\text { Cronbach's } \\
\text { alpha }\end{array}$ & 0.882 & & 0.894 & & 0.890 & & 0.859 & \\
\hline
\end{tabular}


Table A4. Descriptives of independent variables in the analysis

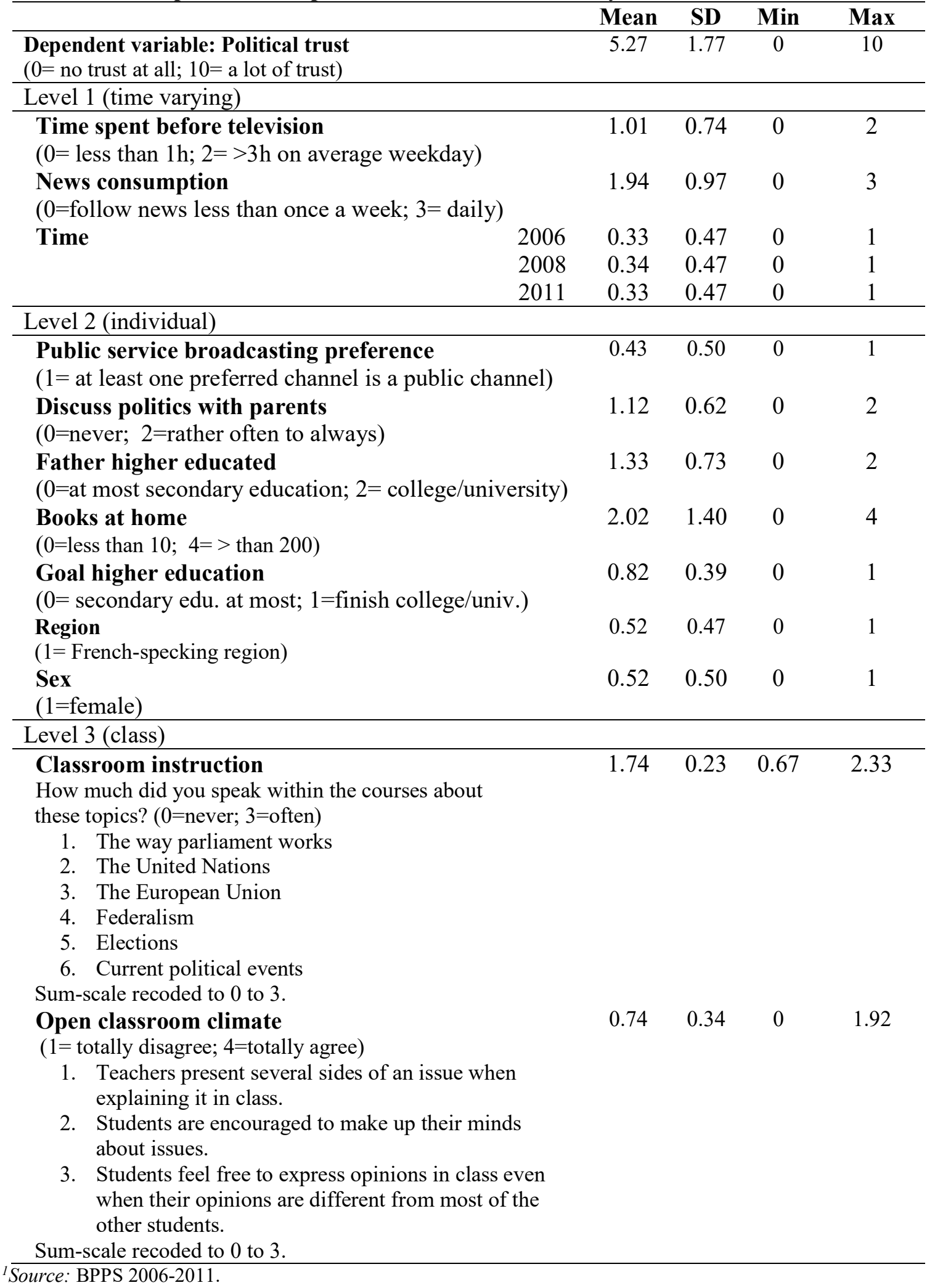

